\title{
Factors Influencing Savings Rate in Malaysia
}

\author{
Dasmin Bin Hashim ${ }^{1}$, Fauzi Bin Pin ${ }^{1} \&$ Mohd Yaziz Bin Mohd Isa ${ }^{2}$ \\ ${ }^{1}$ Graduate Student, Graduate School of Business, Universiti Tun Abdul Razak, Kuala Lumpur, Malaysia \\ ${ }^{2}$ Assistant Professor Dr., Bank Rakyat School of Business \& Entrepreneurship, Universiti Tun Abdul Razak, \\ Kuala Lumpur, Malaysia \\ Correspondence: Mohd Yaziz Bin Mohd Isa, Bank Rakyat School of Business \& Entrepreneurship, Universiti \\ Tun Abdul Razak, Kuala Lumpur, Malaysia. Tel: 1-603-2730-7160. E-mail: mohd_yaziz@unirazak.edu.my
}

Received: March 21, 2017

Accepted: April 11, 2017

Online Published: May 5, 2017

doi:10.5539/ijef.v9n6p52

URL: https://doi.org/10.5539/ijef.v9n6p52

\begin{abstract}
Savings is the balance out of income but is not spent on current consumption. Because we cannot anticipate what would take place in the future, we should set aside some money for unexpected events or emergencies. Without savings, unexpected events can become large financial burdens. Therefore, savings helps an individual or family become financially secure. Due to limited savings and with such low income levels, we are mostly depending on debts to finance our consumption. Currently, Malaysia household debt is amongst the highest in Asia, at $86 \%$ of GDP. There are many factors influencing savings rate in Malaysia. The paper aims to measure the economic variables that may significantly influence toward savings rate in the country.
\end{abstract}

Keywords:savings rate, Consumer Price Index (CPI), economic growth

\section{Introduction}

Saving is an important activity of individual and business organization. In developing country like Malaysia, savings play an important role as a catalyst for economic growth and development. Since 30 years ago, Malaysia has experienced various progress and changes on economic condition. Not too distant ago, the country high savings rate was instrumental to lessen the negative impact of the financial crisis in 1987. By right, saving encourages investment triggering further growth of a country economy. According to Harrod (1939) and Domar (1946), the speed of economic growth is characterized by the ability to save by its people because high savings rate will drive up the rate of investment and consequently will stimulate economic growth. Savings rate is most-widely indicator as a source of economic growth such as in a recent finding by Zulkhibri and Abdul Rani (2016). The authors extended existing literature on savings to include savings bonds raised by the Malaysia government to finance development expenditure and working capital.

\section{Literature Review}

There were several researches on the importance of savings had been carried out in multi context such as individual savings behaviour, household savings pattern as well as at the national savings level, and the word "saving" indicated far more broad-based meanings with numerous explanations. In economic contexts, savings is defined as the residual income after deducting current consumption over a certain period of time (Browning \& Lusardi, 1996; Warneryd, 1999). Eriksson and Hermansson (2014) deepened the understanding of the relationships between banks' advisors and individual customers. The authors provided a more holistic approach to savings behaviour explaining factors that influenced individuals' ability and willingness to save.

In a related study on savings behaviour among Malaysians, Loke (2016) discovered that low and seasonal income earners tend not to live within their means. The findings highlight the importance of savings. The following Table 1 tabulates the rate of Gross Savings as a percentage of GDP among the 8 Asean countries and the same information is in bar chart in Figure 1. The following Figure 2 shows the average rate of Gross Savings of the 8 Asean countries. 
Table 1. Data on gross savings (\% of GDP) for ASEAN countries

\begin{tabular}{lccccccccccc}
\hline Country/Year & 2006 & 2007 & 2008 & 2009 & 2010 & 2011 & 2012 & 2013 & 2014 & 2015 & Average \\
\hline Brunei & 53.4 & 49.9 & 61.8 & 50.9 & 0.0 & 0.0 & 58.3 & 0.0 & 0.0 & 0.0 & 27.4 \\
Malaysia & 38.8 & 38.8 & 38.5 & 33.4 & 33.5 & 34.1 & 30.9 & 29.4 & 29.3 & 28.0 & 33.5 \\
Philippines & 52.8 & 52.2 & 52.2 & 58.0 & 60.8 & 44.9 & 43.2 & 45.3 & 46.4 & 44.9 & 50.1 \\
Singapore & 47.5 & 49.2 & 45.0 & 44.6 & 51.7 & 47.6 & 47.9 & 48.1 & 48.8 & 46.1 & 47.7 \\
Myanmar & 0.0 & 0.0 & 0.0 & 0.0 & 0.0 & 0.0 & 0.0 & 0.0 & 0.0 & 0.0 & 0.0 \\
Thailand & 28.7 & 32.1 & 29.7 & 28.5 & 28.3 & 29.2 & 27.9 & 27.1 & 27.5 & 0.0 & 25.9 \\
Vietnam & 35.6 & 31.5 & 27.2 & 28.5 & 30.5 & 27.7 & 32.0 & 30.1 & 30.4 & 26.9 & 30.1 \\
Indonesia & 27.9 & 26.0 & 26.4 & 31.1 & 32.6 & 33.0 & 32.2 & 30.5 & 31.0 & 0.0 & 27.1 \\
\hline
\end{tabular}

Note. created from the World Development Indicators Series: Gross savings (\% of GDP).

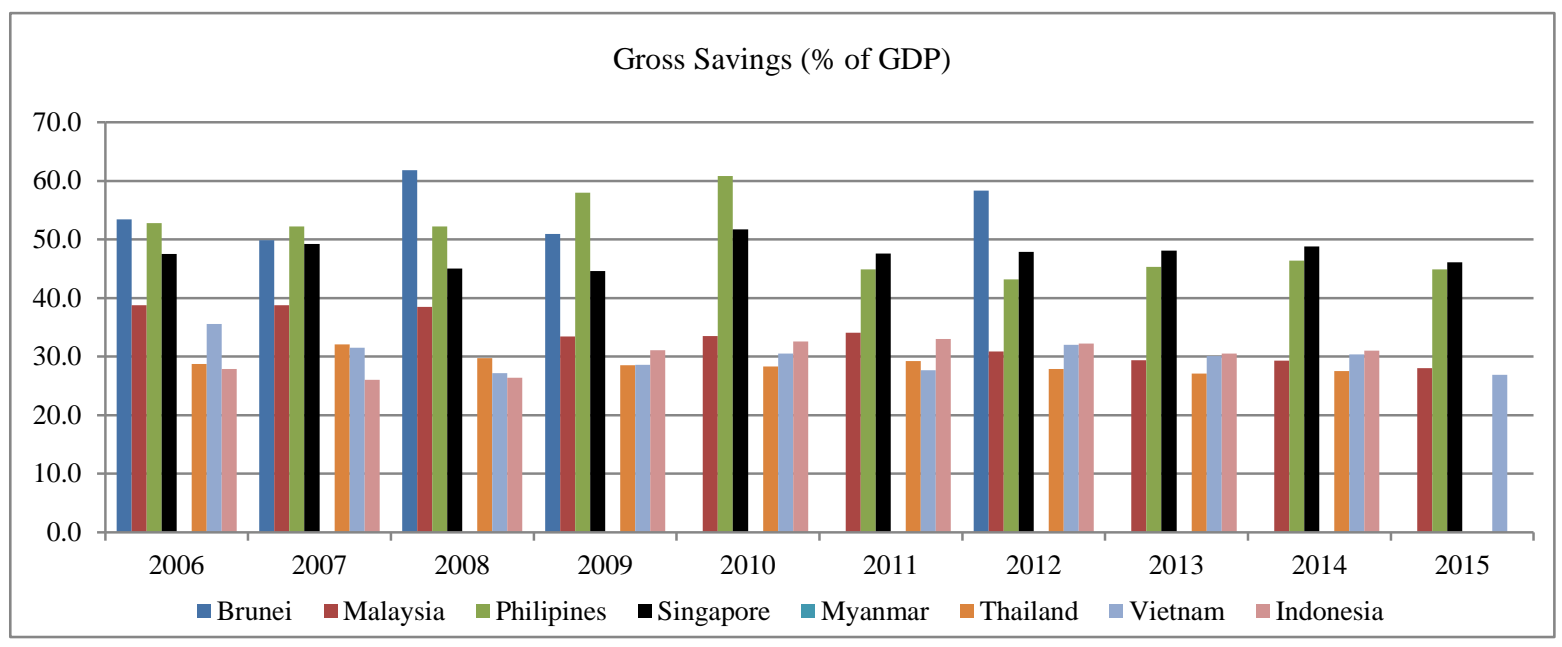

Figure 1. Gross savings (\% of GDP)

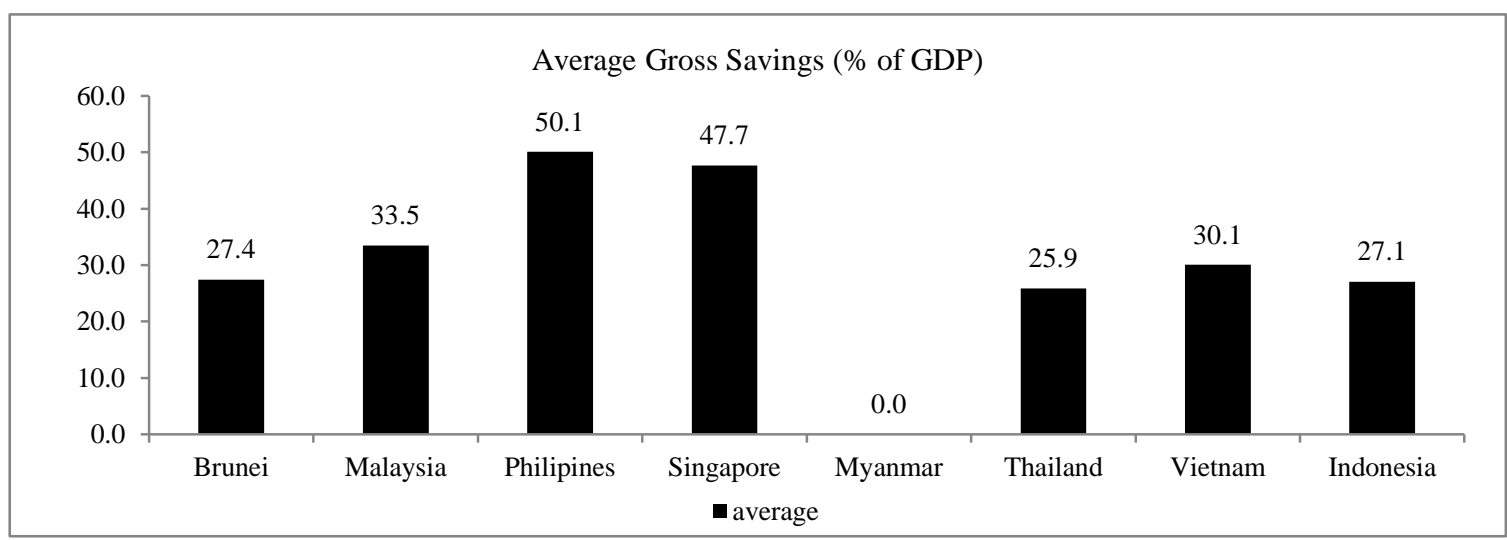

Figure 2. Average gross savings ( $\%$ of GDP) among 8 ASEAN countries

Note.Created from: World Development Indicators Series: Gross savings (\% of GDP).

\subsection{Methodology and Hypothesis Development}

According to Kerlinger (1986), hypothesis is a statement that consists of independent and dependent variable that have relationship and will produce certain results. Once hypothesis was developed, the researcher would know the variables that had been used are valid or not (Sekaran, 2003).

In a recent study by Ruefenacht, Schlager, Maas, and Puustinen (2015), societal norms and values - defined as the interaction between the individual and his or her environment, friends and family - were discovered to influence long-term savings attitudes on individual consumers. The authors drew this conclusion based on 3,800 filled-out surveys returned by targeted respondents in 16 states of Germany. 
For this purpose of this study, the data used obtained from secondary data derived from various sources such as World Bank Report, Bank Negara Malaysia (BNM) Report and Department of Statistic of Malaysia. The data includes are both dependent and independent variables such as interest rate, consumer price index (CPI), and national gross income per capita. The data selected is from 2006 until 2015. This analysis is carried out using Regression Data Analysis.

\section{Dependent Variable}

\subsection{Savings Rate}

Household saving is by definition as the difference between a household's disposable income (such as wages, income of the self-employed and net property income) and its consumption levels (expenditures on goods and services). The household saving rate is arrived at by dividing household savings by the disposable income of a household. According to Yong, Siah, Teh, and Ooi (2008), savings is an excess of resources available in economy that assist to the growth and development process. On the other hand, negative savings rate indicates that a household spends more than it receives as regular income and finances some of the expenditure either by incurring debt or through gains arising from the sale of assets (financial or non-financial) or by running down savings which have been accumulated in the past.

\section{Independent Variables - Interest Rates, Consumer Price Index (CPI) and Gross National Income (GNI) Per Capita}

\subsection{Interest Rates}

Interest rates determine the amount of interest payments that savers will receive on their deposits. An increase in interest rates will make savings more attractive and should encourage savings rates. Contrary, a cut in interest rates will reduce the rewards of savings and will tend to discourage savings as well. However, in the real world, it is more complicated. The link between interest rates and savings is not clear because many factors affect savings rates. Boskin (1978), Giovannini (1983), Mackinnon (1991), Ozcan and Ozcan (2000) agreed that the interest rate elasticity of savings is weak. In view of increasing of household debts in Malaysia, it is becoming increasingly difficult to ignore the important interest rates in attracting savings.

\subsection{Consumer Price Index (CPI)}

CPI is a measure that examines the weighted average of prices of a basket of consumer goods and services, such as transportation, food and medical care. It is calculated by taking price changes for each item in the predetermined basket of goods and averaging them. Changes in the CPI are used to assess price changes associated with the cost of living; the CPI is one of the most frequently used statistics for identifying periods of inflation or deflation. Zulkhibri and Abdul Rani (2016) used the annual growth of CPI as an indicator of inflation.

\subsection{Gross National Income (GNI) Per Capita}

Gross National Income (GNI) per capita is defined as the sum of value-added by all producers who are residents in a nation, plus any product taxes (minus subsidies) not included in output, plus income received from abroad such as employee compensation and property income. GNI measures income or output received by a country both domestically and from overseas. In this respect, GNI is quite similar to Gross National Product (GNP), which measures output from the citizens and companies of a particular nation, regardless of whether they are located within its boundaries or overseas.

The model given below in conceptual and theoretical form to investigate the impact of Interest rate, Consumer Price Index and Gross National Income per capita on Savings rate in Malaysia.

Savings rate $=f$ (interest rate $+\mathrm{CPI}+\mathrm{GNI})$

$$
Y=a+b_{1} X_{1}+b_{2} X_{2}+b_{3} X_{3}+\mu
$$

Where;

$\mathrm{Y} \quad$ = Savings rate in Malaysia

$\mathrm{a} \quad=$ intercept

$\mathrm{X}_{1}=$ interest rate

$\mathrm{X}_{2}=\mathrm{CPI}$ (consumer price index)

$\mathrm{X}_{3}=\mathrm{GNI}$ (gross national income per capita)

$\mu=$ error term 


\section{Empirical Results}

Table 2. Regression results

\begin{tabular}{lcccc}
\hline & Coefficient & Std. Error & T-statistics & P-value \\
\hline Intercept & 33.07 & 26.08 & 1.26 & 0.25 \\
Interest rate & 4.82 & 1.67 & 2.88 & 0.22 \\
Consumer Price Index (CPI) & 0.32 & 0.47 & 0.69 & 0.51 \\
Gross National Index (GNI) per capita & -0.00 & -0.00 & -1.80 & 0.21 \\
\hline R-squared & & 0.95 & & \\
Adjusted $\mathrm{R}^{2}$ & & 0.92 & \\
F-statistics & & 36.59 & \\
Significance F & 0.00 & \\
\hline
\end{tabular}

Therefore, based on theoretical equation, we can write the results as follow;

$$
Y=33.07+4.82 X_{1}+0.32 X_{2}-0.00 X_{3}
$$

Based on the results in Table 2, the Goodness of Fit is measured by the coefficient of determination, $\mathrm{R}$ Squared $\left(\mathrm{R}^{2}\right)$. It indicates the proportion or percentage of the total variation in the dependent variable $\mathrm{Y}$ is explained by all the dependent variables $X$. The results shown the $\mathrm{R}^{2}$ result is 0.95 which means that Savings rate is $95 \%$ explained by regression equation based on Interest rate, Consumer Price Index (CPI) and Gross National Income (GNI). This findings support an earlier study by Eriksson and Hermansson (2014) which deepened and broadened the understanding of the associations of banks' advisors and the savings activity among banks customers. The authors propose three savings behaviour theories that influence savings behaviour.

F-statistic value is 36.59 , while the Significance F-value 0.00. F-value of less than 0.05 means that dependent variable and independent variable are statistically significant in the model; however, Consumer Price Index (CPI) and Gross National Income (GNI) per capita are not acceptable due to P-values is more than 5\%.

Based on the table above, the P-value for interest rate is 0.02 . The result also reveals that there is a positive relationship between interest rate and savings rate. In a rather limited study conducted only in Germany Ruefenacht, Schlager, Maas, and Puustinen (2015) documented perceived importance of societal norms to have a positive influence on savings attitudes among the 3,800 individual respondents in the 16 states of the country.

The P-value of Interest rate is $0.02<0.05$ meaning that independent variable (interest rate) is significantly affected rate of savings. 1 unit increasing in interest rate would increase the savings rate for 4.82 units. Meanwhile, for the Consumer Price Index (CPI), it also has a positive relationship with the savings rate, but lower than interest rate factor at 0.32 units. Any changes in Consumer Price Index (CPI) have only affected $32 \%$ of savings rate. This condition might occur due to people have been affected with increasing in price of the consumer goods and services over the specific time measured. Interestingly, in a recent study on the effects of CPI in Non-Performing Loans (NPL) among banks in Malaysia, Mohd Isa and Zulkifflee (2017) found a negative association between the variables. The authors discovered that CPI did not cause a rise in NPL.

In addition, for the effect of Gross National Income on Savings rate, the result showed that the rate had not been affected by the Gross National Income (GNI) per capita. Conversely, according to Baharumshah \& Soon (2014) the output growth has been negatively affected by inflation. In other words, the authors concluded that an increases in inflation uncertainty resulted in decreases in output uncertainty.

\section{Conclusion}

Saving is an important indicator of economic development where it is viewed as an element which finances domestic investment to achieve economic growth. The purpose of this paper is to examine the savings behavior in Malaysia. The theoretical framework explains the dependent and independent variables, and the results show that independent variables have different effects towards savings rate in Malaysia. There are positive relationships that exist for the interest rate and consumer price index with the savings rate, but negative relation with the gross national income per capita. Besides, there are other factors that might determine the savings rate in Malaysia as mentioned above and the most important factors is economic conditions. People will increase their savings in good economic conditions but reduce their savings when the economy worsen and expenses become higher. 


\section{References}

Baharumshah, A. Z., \& Siew-Voon, S. (2014). Inflation, inflation uncertainty and output growth: What does the data say for Malaysia? Journal of Economic Studies, 370-386. http://dx.doi.org/10.1108/JES-05-2012-0073

Boskin, M. J. (1978). Taxation, savings and the rate of interest. Journal of Political Economy, S3-S27 https://doi.org/10.1086/260692

Browning, M., \& Annamaria, L. (1996). Household saving: micro-theories and micro facts. Journal of Economic Literature, 1797-1855. Retrieved from http://www.econ.nyu.edu/user/bisina/browning-lusardi.pdf

Domar, E. D. (1946). Capital expansion, rate of growth, and employment. Am. Econ. Rev., 343-355. https://doi.org/10.2307/1905364

Eriksson, K., \& Hermansson, C. (2014). Searching for new saving behavior theories: How relationships between banks' customers and advisors affect household saving. International Journal of Bank Marketing, 279-299 http://dx.doi.org/10.1108/IJBM-03-2014-0040

Giovannini, A. (1983). The Interest Elasticity of Savings in Developing Countries: The Existing Evidence. World Development, 11(7). https://doi.org/10.1016/0305-750X(83)90005-0

Harrod, R. F. (1939). An essay in dynamic theory. Econ. J., 49, 14-33. https://doi.org/10.2307/2225181

Kerlinger, F. N. (1986). Foundations of Behavioral Research (3rd ed.). Holt Rinehart \& Winston.

Loke, Y. J. (2016). Living beyond one's means: evidence from Malaysia. International Journal of Social Economics, 2-18. http://dx.doi.org/10.1108/IJSE-11-2013-0248

MacKinnon, J. G. (1991). Critical Values for the Co-integration Tests. In R. F. Engle, \& C. W. J. Granger (Eds.), Long Run Economic Relationships (pp. 267-276). Retrieved from http://qed.econ.queensu.ca/working_papers/papers/qed_wp_1227.pdf

Malaysia Department of Statistic. (n. d.). Retrieved from https://www.dosm.gov.my/v1/

Mohd Isa, M. Y., \& Zulkifflee, M. (2017). Unit Roots and Co-Integration Tests: The Effects of Consumer Price Index (CPI) on Non-Performing Loans (NPL) in the Banking sector in Malaysia. Journal of Advanced Statistics, 16-25. https://dx.doi.org/10.22606/jas.201721003

Ozcan, K. M., \& Ozcan, Y. Z. (2000). Determinants of Private Saving in MENA Region,Iran and Turkey. Research in Middle East Economies (forthcoming). Retrieved fromhttp://www.worldbank.org/mdf

Ruefenacht, M., Schlager, T., Maas, P., \& Puustinen, P. (2015). Drivers of long-term savings behavior from the customers' perspective. International Journal of Bank Marketing, 922-943. http://dx.doi.org/10.1108/IJBM-11-2014-0166

Sekaran, U. (2003). Research methods for business - A skill building approach (4th ed.). John Wiley \& Sons.http://trove.nla.gov.au/version/44715498

World Bank Report. (n. d.). Retrieved from http://www.worldbank.org

Yong, C. C., Siah, K. L., Teh, P. L., \& Ooi, K. B. (2008). Time series analysis on factors influencing savings rate in Malaysia. TheIefai University. Retrieved from https://ideas.repec.org/a/icf/icfjfe/v06y2008i4p50-61.html

Zulkhibrn, M., Abdul, R., \& Mohamed, S. (2016). Term spread, inflation and economic growth in emerging markets: Evidence from Malaysia. Review of Accounting and Finance, 372-392. http://dx.doi.org/10.1108/RAF-04-2015-0056

\section{Copyrights}

Copyright for this article is retained by the author(s), with first publication rights granted to the journal.

This is an open-access article distributed under the terms and conditions of the Creative Commons Attribution license (http://creativecommons.org/licenses/by/4.0/). 